\title{
The Effect of Teaching Reading Comprehension Skills on Translation Quality of Iranian EFL learners
}

\author{
Mehrdad Vasheghani Farahani (Corresponding Author) \\ Faculty of Foreign Languages \& Literature, Science \& Research Branch, Islamic Azad University, Tehran, Iran \\ E-mail: mehrdadfarahani1365@gmail.com \\ Masood Siyyari \\ Faculty of Foreign Languages \& Literature, Science \& Research Branch, Islamic Azad University, Tehran, Iran
}

Received: 24-07-2014

doi:10.7575/aiac.ijalel.v.4n.1p.50
Accepted: 27-08-2014

Published: 01-01-2015

URL: http://dx.doi.org/10.7575/aiac.ijalel.v.4n.1p.50

\begin{abstract}
The purpose of this study was to investigate the effect of teaching reading comprehension skills on translation quality of EFL. In other words, this study sought to see if teaching reading comprehension skills had statically any significant impact translation quality of Iranian EFL learners and if yes, which reading comprehension skill was the most predictive of translation quality of Iranian EFL learners. In order to put this study into practice, these steps were taken. First, in order to assign subjects homogeneity, an OPT (oxford placement test) was given to BA students of English Literature at Beheshti University. Then, a pre- test on translation and a pre-test on reading comprehension were given to the subjects. In the next step, a treatment, on reading comprehension skills only, was given to the subjects. After that a test based on the treatment was given to the subjects. In the final step, two other post-tests, on reading comprehension and translation were given to the subjects to determine if teaching reading comprehension skills had any impact on translation quality of EFL subjects. As the data represents the translation quality of EFL students although increased after they were given some treatments on their reading comprehension; the correlation between reading comprehension skills and the translation quality was not significant (0.585).
\end{abstract}

Keywords: Reading Comprehension, Reading Comprehension Skills Translation, Translation Quality

\section{Introduction}

Translation is a kind of process in which a piece of message from one language (ST) is transferred into another language (TT). "Many scholars believe in the reading-based notion of the translation" (Richard Paul \& Linda Elder, 2002 , p. 14). In other words, they assume translation as a kind of reading, postulating that unless, the translator grasps the content of the ST, he will not be able to translate and transfer the material of the TT. Further, during the last 50 years, translation was deemed a tool for language learning. On those days, the method which was called grammar translation method was in its heyday and translation was of a secondary position.

"The gearing of translation to language teaching and learning may partly explain why academia considered it to be of secondary statue. Translation exercises were regarded as a kind of learning a new language or of reading a foreign language text until one had the linguistic ability to read the original. Study of a work in translation was generally frowned upon once the student had acquired the necessary skills to read the original". (Munday, 2001, p.8).

It was naively assumed that by translating the content of the text under instruction into the native language of the students, they would be able to comprehend better the material in the second language and thus have a better performance in reading comprehension tests. Although this method was successful to some extent, however, it could not meet the needs of the students who wanted to be able to speak well in real situations. Meanwhile, with the advent of communicative language teaching (CLT) Translation was no longer seen as a tool for better learning the second language.

Regarding translation as a communicative activity, different scholars have contributed to connect translation and language teaching.

How can we understand that anybody who can read a text well can thus translate it more adequately? This question is at the center of any theory which regards translation as a kind of reading comprehension. Actually, one of the most important problems in both theory and practice of translation has been the question of whether or not there is a relationship between comprehension ability and translation quality. This question is important in a sense that translation, at the first glance, seems to be a kind of reading, so that one first reads and then translates. SO, this is a very crucial question to determine the relationship between teaching reading comprehension skills and translation quality.

\section{Statement of the Problem}

The increasing role of translation and translation training has turned this kind of activity into the topic of interest in the globalized world. Also, the studies that have been made to date have investigated the impact of translation ability or 
translation practice on different skills in relation to language teaching in an EFL or ESL context. Not much work has so far been reported on the effects of reading comprehension on translation ability. Translation is a kind of complex activity which consists of different areas of knowledge and skills. One of the most important skills in translation is to comprehend the TT. Without capturing the content of the TT, the translator will fail to produce a text which adequately transfers the sense and content of the TT.

The issue of the translator's ability to read and comprehend an SL text has been argued in the works of many scholars and researchers who have investigated the requirements of a translator. Translation research indicates the importance of the problem of the reading comprehension in the process of translation. It seems that if the translator is in the position of a good ability to read and comprehend the source text, s/he will have the capability of adequate translation.

Also, quality in translation is another topic of interest in today's world. These days, translation quality has become a very hot and controversial topic to so many scholars. A very important and significant issue is how to define quality of translation and what criteria are available for translation quality. Translation

Criticism (although under different names) is practiced more consistently and intensively in transfer training institution than in publishing houses. The students' practical translation exercises and their examinations, whether on the elementary or more advanced levels are "corrected" and graded, that is to say; criticized ad evaluated (Resis, 1977, p. 21).

\subsection{Research Hypothesis}

1- There is no relationship between teaching reading comprehension skills and translation quality.

2- None of the reading Comprehension skills is predictive of Iranian EFL learners' translation quality.

\subsection{Research Questions}

1- Does Teaching reading comprehension skills have any statistically significant effect on the translation quality of Iranian EFL learners?

2- If yes, which reading comprehension skill is most predictive of Iranian EFL learners' translation quality?

\section{Review of the Related Literature}

In order to have a full account of what has already been done in this area of research, it seems important to have a survey over the view- points of different scholars towards reading and translation. Actually, there is no single statement, defining the nature of reading; however this shows the fact that with all researches conducted on reading and many articles written on this issue, there are still so many secrets about it which makes it necessary to put it into more experiment to find and agreed definition of what reading is and what happens in the brain of the reader when $\mathrm{s} / \mathrm{he}$ comes up with a text.

\subsection{Translation and language}

As said, many scholars believe in reading- based notion of translation, "All translation tasks begin with a text in one language, go one as one of the language processes that use language as an important component and end up with a text in another language". (Danks\& Griffin, 1997).

As Ziaxi (1997) has put it, "translation is an activity as old as language itself, for both inside and between languages" (p. 23).

In line with the reading-based notion of translation Venuti (2000) says "Language is an indispensable element in the realization of the verbal act. It is a necessary production for communication" (p.12). Also, as Jakobson (1958) observes "the message requires a code, fully or at least partially, common on the addresser and addressee, translation is a dual act of communication. It presupposes the desistence of two distinct codes; the source language and the target language. The fact that the two codes are not isomorphic creates obstacles for the translation operation".

\subsection{The importance of Reading}

In many parts of the world a reading skill of foreign language is often important to academic studies, professional success and personal development. In this regard, Rivers (1980) claims "Reading is an important activity in any language class, not only as a source of information and a pleasurable activity, but also as a means of consolidating and extending one's knowledge of the language" (p.34). He (1981) further claims that "reading skill, once developed, is one which can be mostly easily maintained at a high level by the students themselves without further help from the teacher"(p.37).

\section{Methodology}

\subsection{Participants}

The subjects of this study were 38 Iranian BA students of English Literature who were selected on the basis of random sampling. They were consisted of male and female university seniors who were majoring in English Literature at Beheshti University.

\subsection{Instrumentation}

Regarding the research questions of this study and to reveal the effect of reading comprehension on translation quality, the following instrumentations were used: 


\subsection{Scales for Translation}

Farahzad and Famil Khalil (2012) devised a model for translation quality assessment. Based on this model, the unit of translation is the sentence and each translation of sentences of the source text will be assessed base on the criteria proposed by Farahzad and Khalil.

\begin{tabular}{|c|c|c|c|c|c|}
\hline & 0 & 1 & 2 & 3 & 4 \\
\hline $\begin{array}{l}\text { The translator has translated the source text in accordance } \\
\qquad \text { with its genre }\end{array}$ & & & & & \\
\hline $\begin{array}{l}\text { The translator has made adequate lexical choices in the } \\
\text { translation of the source text }\end{array}$ & & & & & \\
\hline $\begin{array}{l}\text { The translator has used proper spelling. punctuation and grammatically } \\
\text { well-formed sentences in his translation of the source text }\end{array}$ & & & & & \\
\hline $\begin{array}{l}\text { The translator has used a culturally appropriate language in } \\
\text { his translation of the scurce text }\end{array}$ & & & & & \\
\hline $\begin{array}{c}\text { The translator has properly expressed the linguistic function } \\
\text { and the speech acts of the source text in the target text }\end{array}$ & & & & & \\
\hline $\begin{array}{l}\text { The translator has used a proper register for transferring the source } \\
\text { text author's personal view point and stance in the target language }\end{array}$ & & & & & \\
\hline $\begin{array}{l}\text { The translator has produced a coherentand well-organizedicohesive) } \\
\text { piece of writing in his translation of the source text }\end{array}$ & & & & & \\
\hline
\end{tabular}

Figurer 1. Farahzad and Famil Khalil Translation Scoring Model

\subsection{Oxford Placement Test (OPT)}

To homogenize subjects based on their general abilities of language and to reach a better category of them, an OPT was administrated.

\subsection{The TOEFL}

The TOEFL which was used in this study was the test released by the Education Testing Service in 2010. Typically, the TOEFL is composed of four sections: Listening comprehension, Structure and Written Expression and Reading Comprehension. Actually, for the ease of administration and regarding the purpose of the study, only reading comprehension section was included in this study.

\subsection{Translation Text}

To assess the quality and ability of the students' translation, two pieces of text which had been produced by native speakers of English, were exploited. The level of difficulty of the text matched the level of subjects.

\subsection{Design}

The design used in this study was pre-experimental "one group pre-test post- test design in nature.

\subsection{Procedure}

After selecting the subjects randomly, they were given an OPT. This test was administrated to determine their average language proficiency level based on their general language abilities. After that, a pre-test on reading comprehension and a pre- test on translation were given to the subjects. Next, the participants were given treatment/ instructions on their reading comprehension skills, only. After that a test based on their treatment was given to the subjects. Finally, they were given two other tests on translation and reading comprehension to see if the instruction on their reading enhanced their translation quality. 


\section{Analysis of Data}

\subsection{Oxford Placement Test}

Oxford Placement Test (OPT) is usually conducted to have subjects homogenized. As can be seen, $50 \%$ of the subjects were rated as high, $39.5 \%$ as intermediate and $10.5 \%$ as low.

\begin{tabular}{llccc}
\hline & Frequency & Percent & Valid Percentage \\
\hline Valid & $35-40$ (High) & 19 & 50 & 50 \\
$30-35$ (intermediate) & 15 & 39.5 & 39.5 \\
& $<30$ (Low) & 4 & 10.5 & 10.5 \\
100 & & & \\
Total & 38 & 100 & 100 \\
\hline
\end{tabular}

\subsection{OPT Results}

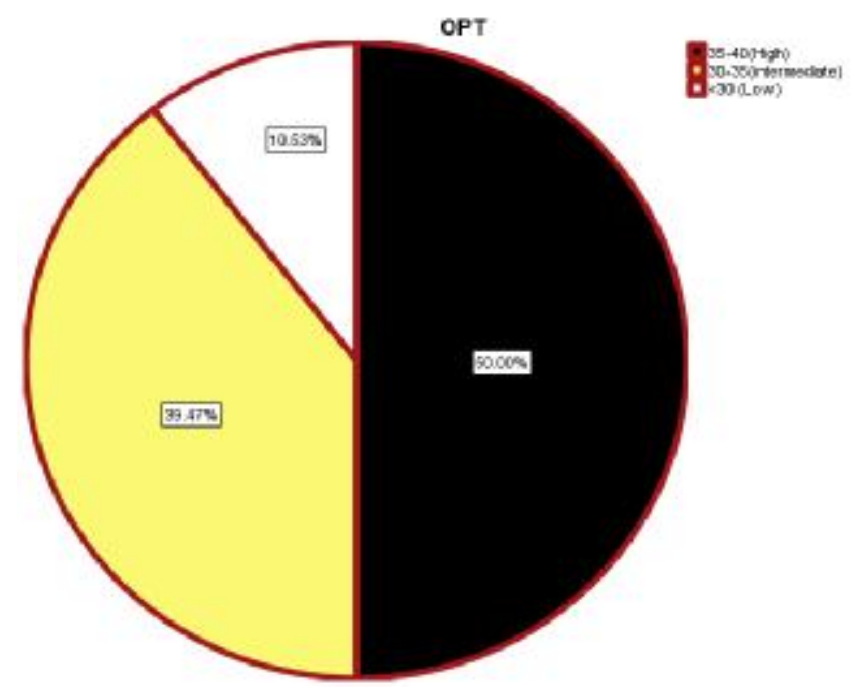

The table bellow represents the general level of the subjects who participated in the study. As the data show, the mean of the scores is 34,13 which means that they are ranked as intermediate level subjects.

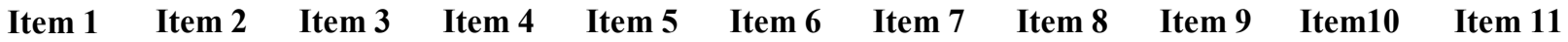

$\begin{array}{ccccccccccc}38 & \mathbf{3 4 . 1 3 1 6} & \mathbf{. 6 1 9 9 3} & \mathbf{3 . 8 2 1 5 0} & \mathbf{1 4 . 6 0 4} & \mathbf{- 1 . 8 0} & \mathbf{0 . 3 8 3} & \mathbf{5 . 3 9 9} & \mathbf{. 7 5 0} & \mathbf{1 9 . 0 0} & \mathbf{3 9 . 0 0 0} \\ \mathrm{N} & \text { Mean } & \text { Standard } & \text { Standard } & \text { Variance } & \text { Skewness } & \text { Standard } & \text { Kurtois } & \text { Standard } & \text { Minmum } & \text { Maximu } \\ \text { (Valid } & & \text { Error of } & \text { Deviation } & & & \text { Error of } & & \text { Error of } & & \\ \text { \&Missing) } & & \text { Mean } & & & & \text { Skewness } & & \text { Kurtois } & \end{array}$

Table5.3.Tests of Normality (reading comprehension)

\begin{tabular}{llll}
\hline & \multicolumn{2}{l}{ Kolmogorov-Smirnov $^{\mathrm{a}}$} & Sig. \\
\cline { 2 - 4 } & Statistic & $D f$ & .002 \\
\cline { 2 - 4 } reading pretest & .184 & 38 & .000 \\
reading posttest & .231 & 38 & \\
a. Lilliefors Significance Correction & & & \\
\hline
\end{tabular}


In order to check the measurement properties of the reading comprehension tests used in pre-test and post-test, first Kolmogorov-Smirnov was employed. As can be seen, the tests are not normally distributed (002); as a result notparametric approach is used.

Table 5.4. Ranks

\begin{tabular}{lllll}
\hline & & N & Mean Rank & Sum of Ranks \\
\hline $\begin{array}{l}\text { reading posttest - reading } \\
\text { pretest }\end{array}$ & Negative Ranks & $4(\mathrm{a})$ & 11.38 & 45.50 \\
& Positive Ranks & $33(\mathrm{~b})$ & 19.92 & 657.50 \\
& & & \\
& Ties & $1(\mathrm{c})$ & \\
\cline { 2 - 4 } & 38 & & \\
& Total & 38 & \\
\hline
\end{tabular}

a reading posttest $<$ reading pretest

$b$ reading posttest $>$ reading pretest

$\mathrm{c}$ reading posttest $=$ reading pretest

Table 5.4 provides the main Wilcoxon Signed ranks test results, which is indicative of the fact that the posttest is larger than the pretest mean; $\mathrm{Z}=4.628, \mathrm{p}<.05$. In other words, it means that the reading comprehension scores of the students increased after having been taught the reading comprehension skills during the treatment of the study.

Table 5.5. Descriptives

\begin{tabular}{|c|c|c|c|}
\hline & & Statistic & Std. Error \\
\hline \multirow{6}{*}{ translation pretest } & Mean & 19.1974 & .81951 \\
\hline & Std. Deviation & 5.05181 & \\
\hline & Minimum & 00 & \\
\hline & Maximum & 26.00 & \\
\hline & Skewness & -1.601 & .383 \\
\hline & Kurtosis & 4.423 & .750 \\
\hline \multirow{7}{*}{ translation posttest } & Mean & 21.7763 & .44213 \\
\hline & Std. Deviation & 2.72550 & \\
\hline & Minimum & 13.50 & \\
\hline & Maximum & 27.50 & \\
\hline & Range & 12.00 & \\
\hline & Skewness & -.624 & .383 \\
\hline & Kurtosis & 2.237 & .750 \\
\hline
\end{tabular}

To determine what mean-comparison statics should be used, the descriptive statics of the pre-test and post-test were calculated, and then the data were calculated for normality by Kolmogorov-Smirnov test. As the results of normality show, translation pre-test and post-test are deviant from normal distribution; thus, non-parametric approach is used.

Table 5.6 Ranks

\begin{tabular}{lllll}
\hline & & $\mathrm{N}$ & Mean Rank & Sum of Ranks \\
\hline $\begin{array}{l}\text { translation posttest } \\
\text { translation pretest }\end{array}$ & Negative Ranks & $9(\mathrm{a})$ & 10.78 & 97.00 \\
& Positive Ranks & $27(\mathrm{~b})$ & 21.07 & 569.00 \\
& $2(\mathrm{c})$ & & \\
\cline { 2 - 3 } & Ties & 38 & \\
\hline
\end{tabular}

a translation posttest $<$ translation pretest

b translation posttest $>$ translation pretest

c translation posttest $=$ translation pretest

Table 5.6 provides the signed ranks tests results which is indicative of the fact that the post- test is not significantly larger than the pre-test mean; $Z=-3.715 \leq .05$, which means that the translation quality of the subjects did not increase significantly after having been taught reading skills during the treatment. 


\begin{tabular}{llllll}
\hline & Spearman's & & & & \\
& Rho & reading pretest & translation pretest & reading posttest & translation posttest \\
\hline reading & Coefficient & 1.000 & .072 & .221 & .224 \\
pretest & Sig. (2-tailed) & & .667 & .182 & .177 \\
& $\mathrm{~N}$ & 38 & 38 & 38 & 38 \\
\hline translation & Coefficient & .072 & 1.000 & .043 & $.664^{* *}$ \\
pretest & Sig. (2-tailed) & .667 & & .796 & .000 \\
& $\mathrm{~N}$ & 38 & 38 & 38 & 38 \\
\hline reading & Coefficient & .221 & .043 & 1.000 & .141 \\
posttest & Sig. (2-tailed) & .182 & .796 & & .397 \\
& $\mathrm{~N}$ & 38 & 38 & 38 & 38 \\
\hline translation & Coefficient & .224 & $.664^{* *}$ & .141 & 1.000 \\
posttest & Sig. (2-tailed) & .177 & .000 & .397 & \\
& $\mathrm{~N}$ & 38 & 38 & 38 & 38 \\
\hline
\end{tabular}

** Correlation is significant at the 0.01 level (2-tailed).

* Correlation is significant at the 0.05 level (2-tailed).

Table 5.7 provides the correlation between translation quality and reading comprehension. As can be seen, reading posttest scores is (.141) larger than (0.05). Thus, there is no relationship between reading comprehension and translation quality.

Table 5.8. Correlations

\begin{tabular}{lllllllllll}
\hline & & skill 1 & skil2 & skill 3 & skill 4 & skill 5 & Skill6 & skill 7 & skill 8 & Skill9 \\
\hline \multirow{3}{*}{$\begin{array}{l}\text { translation } \\
\text { posttest }\end{array}$} & Spearman r & -.103 & .152 & .302 & -.023 & .309 & -.177 & .307 & -.188 & 175 \\
& Sig. & & & & & & & & & \\
& (2-tailed) & .546 & .368 & .069 & .893 & .063 & .301 & .828 & .264 & .230 \\
& $\mathrm{~N}$ & 38 & 38 & 38 & 38 & 38 & 38 & 38 & 38 & 38 \\
\hline
\end{tabular}

*. Correlation is significant at the 0.05 level (2-tailed).

Table 5.8 represents the relationship between translation post-test and sub-skills of reading comprehension. As can be seen, out of nine skills taught during the treatment, none of them had any significant relation with translation quality of subjects.

Table 5.9. Correlations

\begin{tabular}{llr}
\hline & & \multicolumn{2}{c}{$\begin{array}{c}\text { Treatment (Reading } \\
\text { Comprehension Skills) }\end{array}$} \\
\hline & Spearman's rho & .093 \\
Translation Post-test & Sig. (2-tailed) & .585 \\
& $\mathrm{~N}$ & 38 \\
\hline
\end{tabular}

Table 5.9 shows the relationship between treatment on reading comprehension and translation quality. As can be seen, treatment on reading comprehension $(0.585)$ has no impact son translation quality of the subjects.

\section{Discussion}

This research sought to find out whether or not there was a relationship between teaching reading comprehension skills and translation quality of the Iranian EFL learners and if yes, which reading skill was the most predictive of increasing translation quality? In details, was there any significantly important relationship between teaching reading comprehension skills and translation quality of EFLs and which reading skill was mostly predictive of such relationship? In this regard, an OPT was given to the subjects to verify their general knowledge of English, Then a pretest on reading comprehension and on translation were given to the subjects. Next, subjects were provided with some treatment on their reading comprehension and a test based on them. Finally, two other post-tests, on reading comprehension and on translation were given to the subjects to test the effects of treatment on translation quality.

Considering the first research question; that is to say, does teaching reading comprehension skill have any statically significant impact on translation quality, as the data represents, the translation quality of the subjects increased after the 
treatment. It means that the translation quality of the subjects increased after the treatment on their reading comprehension skills. However, this enhancement has nothing to do with treatment (table5.9). Indeed, some other intervening variables might have impact on translation posttest. As a result, it can be concluded that the first hypothesis of the research; that is to say, there is no relationship between teaching reading comprehension skills and translation quality of Iranian EFLs, is accepted.

In line with the hypothesis stated, some scholars have put forward different ideas. As an example, Delisle (1980) has pointed out that linguistic and reading comprehension competence are the necessary pre-conditions for a good translation; however, they are not enough for a professional act of translation.

Gerding-Salas states that "apart from reading comprehension ability, the knowledge of specialized subjects derived from specialized training and a wide cultural background, and the global vision of cross-cultural and interlingual communication, it is a must to learn how to handle the strategic and tactical tools for a good translating performance".

However, to reject the idea that reading comprehension and translation quality have nothing to do with each other, different scholars have suggested different notions. With regard to reading comprehension and translation quality, generally all the researchers agree that on the conditions that reading skills of the trainees increase, their translation quality will enhance. As an example, Shereve (1985, p. 105) says that "in translation, the translator faces a text in the source text which $\mathrm{s} / \mathrm{he}$ will have to read it first for comprehension. The translator begins the job by reading the original for two purposes. First, to understands what it is about and second to analyses it from a translator point of view.

Also, in line with the positive relationship between reading comprehension and translation quality, Nourozi (1999, p. 103) has specified the concept of reading as a skill has evolved in recent years and has come to be reflected in types of ELT materials available, our approaches to material design for teaching reading to translator trainees could be affected, so that reading materials could more effectively provide learners with useful texts or affective strategies to improve their translation abilities. Furthermore, translation research indicates the significance of the problem of reading comprehension in the process of translation. It seems that if the translator has a good ability to read and comprehend the source text, s/he will be capable of adequately translating, even though his /her other abilities may not be at a high level.

In this regard, Newmark (1990, p.25) has specified. Understanding the text requires both general and close reading. General reading to get the gist; here you have to read encyclopedias, text books or specialist papers to understand the subjects and concepts. Close reading is required in any challenging text of words both out and in the context.

Regarding the second research question; that is to say, the reading skill(S) which is most predictive of translation quality of EFLs, the data were analyzed. To do so, the skills' scores were correlated with the translation quality scores on the posttest. As the data represent, no reading comprehension skills have statically impact on translation quality. Thus, the second research hypothesis is also accepted.

In line with the above-mentioned result, Eghlimi (1999), in her M.A thesis on the "Evaluating of the Relationship between College Students' Translation Ability and their Reading Comprehension Ability" used five tests including two sections of translation" essay type and multiple choice and three sections of reading comprehension: multiple choice, fill in the blanks and functional-notional. She could not find any relationship between multiple choices and fill in the blanks test of reading comprehension and the translation ability of the students. However, the results showed a corresponding relationship between all three reading comprehension test and translation ability of the subjects.

\section{Conclusions \& Pedagogical Implications}

Two conclusions, with some caveats, can be drawn from this study. Firstly, the result of the study does not reject the null hypothesis which maintains; "there is no relationship between teaching reading comprehension skills and translation quality of Iranian EFLs. Actually, there is no positive relationship between teaching reading comprehension skills and translation quality of Iranian EFLs. Secondly, as the data represents, no skill might have statically significant impact on translation quality of Iranian EFLs.

In sum, the present study which was conducted on Iranian EFLs, has demonstrated the negative relationship between teaching reading comprehension skills and translation quality of Iranian EFL students.

\subsection{Implications}

There are certain implications arising from the findings and conclusions of this study for language practitioners. Reading is one of the bases of language which can help learners to develop their language skills. Most of the information we get about the world is through reading; it means reading comprehension plays a significant role in our everyday life.

\subsection{Implications for translation teachers}

Based on the above discussion and the data analyzed, it is understood that the question of how and what teach for reading comprehension cannot be a central issue in text translation. The present study can play an important role for ESL and EFL teachers since it focused on the role of reading in the process of teaching translation skills to the Iranian EFLs.

For the actual translation-practice sessions, workshops could be designed in which:

1. The material to be translated in each session is selected by teacher according to previously taught skills; taking into consideration the degree of difficulty, the text content, the reading skill taught and the translation problems to be solved. 
2. All translation activities should be under close supervision of the teacher

\subsection{Implication for Syllabus design}

The findings of this study may be beneficial to syllabus designers. While translation courses are being offered in many universities, it seems that not much attention has been paid to translation courses and general English knowledge of the trainees. From the finding of the present study, it can be said that for the translation preliminary courses. It is proposed that the teachers and instructors provide their subjects with as translation courses as possible. The more courses they pass the better translation they might yield.

\subsection{Implication for Translation Trainees}

At least for pedagogical purposes, especially for translation trainees, such finding could be useful for the allotment of time and resources of suitable reading comprehension skills to the trainees. It is recommended that the translation trainees who take reading courses or who read texts for the purposes of translation focus on translation skills rather than reading skills. Also, it is recommended that the trainees read the text carefully to make sure that they have understood it fully and after that start the task of translation.

\subsection{Suggestions for Further Research}

In what follows, some of the issues that need more investigation on the relationship between teaching reading comprehension skills and translation quality of EFLs will be addressed.

This study has focused on Iranian EFL learners at intermediate level. The same research can be done on EFL learners at advanced or elementary levels. Also, this research was conducted on one group only; another research can be done based on true experimental method, in which there are two groups for the study. This research focused on the relationship between teaching reading comprehension skills and translation quality. Another research can be designed to address the effects of teaching translation skills on reading comprehension quality of Iranian EFLs.

The present thesis has been conducted with Iranian intermediate level English learners. The participants have been selected based on their language proficiency level. Not only language proficiency level, but also learners' age is a vital factor in having poor or rich translation quality. Additional researches are required to investigate the relationship between age and translation quality.

Also, being limited to the scope of the research, the researcher could not differentiate between the gender and translation quality. Extra research can be conducted to investigate the relationship between gender and translation quality.

\subsection{Limitations of the Study}

As with any research project, the current study faced a number of limitations, some of which could have influenced the findings and confined the generalizability of the results. What follow is the limitations over which the researcher had little or no control

Since participants were chosen based on their language proficiency, there was no control on the range of learners' age;

Since participants were chosen based on their language proficiency; unfortunately there was no control over the gender of the subjects;

The last but by no means the least limitation mentioned here was about the amount of prior knowledge each learner had. There was no control on students' amount of background knowledge or their content familiarity.

\section{References}

Adab, B. (2000). Evaluating translation competence. Amsterdam : Jihn Benjamins Publishing Company.

Al-Qinai, J. (2000). Translation quality assessment. Strategies, Parameters and Procedures. London: Longman.

Amman, S. (2003). 7 Keys to comprehension: How to help your kids read it and get it. New York: Three Rivers Press. Anderson, j, C. (1984). Reading in a foreign language: a reading problem or language problem. London: Longman.

Anderson, R, C., \& Pearson, P.D. (1988). A schema-theory view of basic process in reading comprehension. Cambridge: Cambridge University Press.

Backer, M. (1992). In other words: A course book on translation. London: Routledge.

Beeby, L.A. (1996). Teaching translation from Spanish to English. Ottawa: University of Ottawa Press.

Beeby, L.A. (2000). Translation and translating: Theory and Practice. Ottawa: University of Ottawa Press.

Bassnet, S. (2002). Translation studies. London: Routledge Publications.

Berman ,S. (2005). Nation, Language and Ethics of Translation. Prinston: Prinston University press.

Bernhadt,E.B. (1988). Reading development in second language: theoretical, empirical and classroom perspectives. Norwood: Ablex.

Biguenet, J. (1989). The craft of translation. Hicago: The University of Chicago Press.

Brown, H. D. (2000). Principles of language learning and teaching: 4th ed. White Plains, NY: Addison Wesley Longman. 
Campell, S. (1998). Towards a model of translation competence. New York: Amsco.

Carrell,P.L. (1981). Three components of background knowledge in reading comprehension: Oxford: Blackwell.

Catford, J. (1964). A linguistic theory of translation. Oxford: Oxford University Press.

Chastain, k. (1988). Developing second language skills: Theory and practice ( $3^{\text {rd }}$ ed.). Florida: Harcourt Brace Jovanovich.

Danks, H. and Griffen, J. (1997) Reading and Translation, a psychological Perspective. Florida: Harcourt Brace Jovanovich.

David ,C. (1998). A Dictionary of Linguistics and Phonetics, 4th Ed. Newyork: Blackwell.

Duff,A (1989). Translation. Oxford: Oxford University Press.

Eghlimi, N. (1999). Research on the Evaluation of the Relationship between Students' Translation Ability and Their Reading Comprehension Ability. Iran: University of Science and Technology.

Farahzad. F. \& Famil Khalil. (2012) Validation of a scale for Translation Quality Assessment: A Model Revisited. Translation Studies.

Gentzler,E. (1993). Contemporary translationtheories. London: Routledge.

Gibson, E.J \& Levin, L. (1976). The psychology of reading. The Massachusetts Institute of Technology (MIT).

Grabe, W. (1997). Reading Research and its Implications for Reading Assessment. Oxford: Oxford University Press.

Gutt- Kfouri, C.A. (2004): Testing and evaluating in translation classroom. Oxford: Blackwell.

Gut, E.A. (1991). Translation and relevance: Cognition and context. Oxford: Blackwell.

Halliday, M.A.K. (1978). Language as social semiotic. London: Edward Arnold.

Hatim,B., \& Mason, I. (1990). Translator as communicator. London: Routledge.

Hatim,B., \& Mason, I.(1997). Discourse and the translator. London: Longman.

Hatim,B., \& Munday,J. (2004). Translation: An advanced resource book. London: Longman.

Hawking, B, (1991). Teaching children to read in second language. USA: Newbury House Publisher.

Holmz- Manttari, J. (1984). Translatologies- Theories and Methods. Helsinki: Suomalian Tiedeakatemin.

House, J. (2001).Translation quality assessment: A model revisited. Tubingen: narr

Hulst, D,(1965), Evaluation of machine translations by reading comprehension Tests and Subjective Judgments, Mechanical Translation, Vol. 8

Khanmohammad ,H. \& Osanloo, M(2011). Moving toward objective scoring: A Rubric for Translation Assessment. Iran Kelly, L. (1969). 25 Centuries of Language Teaching. Rowley, Mass: Newbery House.

Koller, W. (1979). The concept of equivalence and the object of translation translation studies. Target, 7 (2), 191

Kussmaul,P. (1995). Training the translator. Amesterdam: John Benjamins.

Lambert, D. \& Lins,D.(2000) Understanding Assessment: Purpose, Perceptions, Practice. London: Rutledge.

Levere,A. (1993). Translation/ history/ culture: A source book. New york: Routledge.

McCarty, M. (1991). Discourse analysis for language teachers.Tehran: Rahnama Publications,( Chapter 7).

Millar,D. (2000). Translating text and context:Translation studies and systematic functional linguistics. Cambridge :Cambridge University Press, ( pp.33-105).

Mirhassani, A .(2003) Theories, Approaches and Methods in Teaching English as a Foreign Language. Tehran: Zabankade.

Mohagegh,N. (2002). Reading for translation \& non- translation purposes. MA.thesis. Research and branch of Azad University.

Munday, J. (2001). Introducing translation studies. London: Routledge.

Nategh, R. (1990). Translation in language Teaching Methods and Translation: Ankara University, Iran.

Neubert, A. (1992). Translation as a text: Kent: Kent State University Press.

Newbert, A. (1992). Competence in translation . Kent: Kent state university press.

Newmark,P. (1988). A text book of Translation. Oxford: Oxford University Press.

Newmark,P. (1991) .About Translation. Clevedon: Multilingual Matters.

Nida,E. (1964). Toward a science of translation:Lieden: Lodon: Routledge.

Nord, C. (1992). Text analysis in translator training. Amesterdam: John Benjamins.

Pym, A. (2007).Philosophy and Translation. Cleveden: Multilingual Matters, Ltd.

Ramzjou, 1. (2004). To be a good translator. Translation Journal, (2). 20-30 . Mashad: Mashad university press. 
Reisis,K. (197)1. Translation Criticism- The potentials and Limitations: Manchester: St. Jerome Publishing co.

Reisis,K. (2000). Type, kind and individuality of text. Decision makingin translation. Manchester: St. Jerome Publishing co.

Richards J C., Plaat, J and H, (1992). Longman Dictionary of Language Teaching and Applied Linguistics. UK: Longman.

Rivers, W.M. (1968). Teaching foreign language skills. Chicago: The University of Chicago Press.

Saresca, J.(1958). Some Psychological Methods for Evaluating the Quality of Translations. Heidelburg: Quell and Merry

Selinker, L. 7: Shaffner, C. (1997). From Good" to "Functionally appropriate: Assessing Translation Quality. Current Issues in Language and Society. USA: Amesco.

Shereve, M, Shaffner, C, Danks. H.,nd Griifen, J(1993). Is there a special kind of reading for Translation? Germany: Lambert Publications.

Snell- Hornby, M. (1988). Translation Studies: An integrated approach. Amesterdam: Hohn Benjamins.

Solhjou, A. (2007). Discourse and translation (4th edition).Tehran: Rahnama Publications, (pp. 33-67).

Shttleworh,M. \&(1997). Dictionary of translation studies. Manchester: St. Jerome translation quality assessment. Current Issues in Language and Society, 4 (1), 6-34.

Toury,G. (1978). The nature and norms of translation. Leuven: ACCO.

Urquh, A.H and Weir. C.J. (1998). Reading in a second Language: Process, Product and Practice. London: Routledge.

Brock, R. Van den. 1985. Second thoughts on Translation Criticism: A model of its Analytic Function "in the Multiplication of Literature.Ed. T. Herman. London: Crom Helm.

Venuti.L. (2000). The translation Studies Reader. London, Newyork: Routledge. Venuti, L. (1995). The translator invisibility: A history of translation. London: Routledge.

Walter, C. (2004). Transfer of reading comprehension skills to L2. Applied Linguistics, 25(3).

Waddington, C. (2001). Different methods of evaluating of student translations: The question of validity. Meta, 46, 1331 .

Wolf, D.F. (1993). A Comparison of assessment tasks used to measure EFL reading comprehension. Brooklyn, NY: Hang Loose Press.

Wills, W. (1974). Translation quality assessment. Turbinge: Gunter Narr.

Wills,W. (1982). The science of translation” problems and methods. Turbinge: Gunter Narr.

Ziaxi, T. (1997). Reading Transactions in Translation. Brooklyn, NY: Hang Loose Press. 